Article

\title{
Detection of Cyclic Imine Toxins in Dietary Supplements of Green Lipped Mussels (Perna canaliculus) and in Shellfish Mytilus chilensis
}

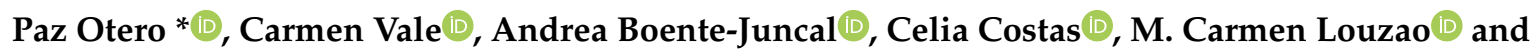 \\ Luis M. Botana \\ Departamento de Farmacología, Farmacia y Tecnología Farmacéutica, Facultad de Veterinaria, Universidad de \\ Santiago de Compostela, 27002 Lugo, Spain; mdelcarmen.vale@usc.es (C.V.); \\ andrea.boente.juncal@usc.es (A.B.-J.); celia.costas.sanchez@usc.es (C.C.); mcarmen.louzao@usc.es (M.C.L.); \\ luis.botana@usc.es (L.M.B.) \\ * Correspondence: paz.otero@usc.es; Tel.: +34-982-822212
}

Received: 27 July 2020; Accepted: 21 September 2020; Published: 24 September 2020

\begin{abstract}
Seafood represents a significant part of the human staple diet. In the recent years, the identification of emerging lipophilic marine toxins has increased, leading to the potential for consumers to be intoxicated by these toxins. In the present work, we investigate the presence of lipophilic marine toxins (both regulated and emerging) in commercial seafood products from non-European locations, including mussels Mytilus chilensis from Chile, clams Tawerea gayi and Metetrix lyrate from the Southeast Pacific and Vietnam, and food supplements based on mussels formulations of Perna canaliculus from New Zealand. All these products were purchased from European Union markets and they were analyzed by UPLC-MS/MS. Results showed the presence of the emerging pinnatoxin-G in mussels Mytilus chilensis at levels up to $5.2 \mu \mathrm{g} / \mathrm{kg}$ and azaspiracid-2 and pectenotoxin-2 in clams Tawera gayi up to $4.33 \mu \mathrm{g} / \mathrm{kg}$ and $10.88 \mu \mathrm{g} / \mathrm{kg}$, respectively. This study confirms the presence of pinnatoxins in Chile, one of the major mussel producers worldwide. Chromatograms showed the presence of 13-desmethyl spirolide $C$ in dietary supplements in the range of 33.2-97.9 $\mu \mathrm{g} / \mathrm{kg}$ after an extraction with water and methanol from $0.39 \mathrm{~g}$ of the green lipped mussels powder. As far as we know, this constitutes the first time that an emerging cyclic imine toxin in dietary supplements is reported. Identifying new matrix, locations, and understanding emerging toxin distribution area are important for preventing the risks of spreading and contamination linked to these compounds.
\end{abstract}

Keywords: 13-desmethyl spirolide C; pinnatoxin-G; dietary supplements; Perna canaliculus; Mytilus Chilensis; UPLC-MS/MS

Key Contribution: Analytical methodology to identify marine lipophilic toxins in dietary supplements. First detection of the non-regulated toxin 13-desmethyl spirolide $C$ in food supplements of Perna Canaliculus. Presence of pinnatoxin-G in Mytilus Chilensis.

\section{Introduction}

Lipophilic marine toxins in mollusc constitute an important threat to human health and high number of intoxications occur every year [1]. The legislated group of lipophilic marine toxins includes four different chemical groups: yessotoxins (YTXs) azaspiracids (AZAs), pectenotoxins (PTXs), and okadaic acid (OA) and its derivatives, the dinophysistoxins (DTXs). Only few compounds of each group are regulated: yessotoxin (YTX), homo-yessotoxin (Homo-YTX), 45-hydroxy-yessotoxin (45-OH-YTX), 45-hydroxy-homo-yessotoxin (45-OH-homo-YTX), azaspiracid-1 (AZA-1), azaspiracid-2 (AZA-2), azaspiracid-3 (AZA-3), pectenotoxin-1 (PTX-1), pectenotoxin-2 (PTX-2), OA, dinophysistoxin-1 
(DTX-1), dinophysistoxin-2 (DTX-2), and dinophysistoxin-3 (DTX-3). When LC-MS methodology is used, the concentration in a sample has to be referred to a predominant toxin of the group, named the reference compound (RC) and using the toxicity equivalency factors (TEFs) values for the other analogues from the same group [2,3]. The RCs for lipophilic toxins are YTX, AZA-1, PTX-2, and OA. The use of TEFs requires the knowledge of the toxicity of each analogue present in a sample to link analytical data into their toxicity $[2,3]$. Several countries have proposed limits in molluscs for some lipophilic toxins, for example, in the European Union (EU), levels in shellfish for human consumption have to be below $3.75 \mathrm{mg}$ eq YTX/kg, $0.16 \mathrm{mg}$ eq AZA, and $0.16 \mathrm{mg}$ eq OA/Kg (for the OA and PTX toxin group) [4,5]. Until 2013, all official determinations were performed through in vivo assays, but after that year, the analysis by LC-MS/MS were progressively increasing, according to the legislation $15 / 2011$ [6].

In the past decade, evidence has grown for the occurrence of non-regulated toxins, spirolides (SPXs) and pinnatoxins (PnTXs), in mollusc from EU waters [7-14]. These compounds belong to the cyclic imine (CIs) group and chemistry, they are macrocyclic molecules with imine and spiro-linked ether moieties $[15,16]$. Their mode of action is related to the interaction with muscle-type and neuronal nicotinic acetylcholine ( $\mathrm{ACh}$ ) receptors (nAChR) [9]. No incident of human intoxication has been attributed to CI so far and currently there are no regulations in molluscs in EU or in other regions worldwide. However, EFSA has recommended a maximum level of $400 \mu \mathrm{g}$ sum of SPXs/kg shellfish meat [17].

The high occurrence of CIs leads us to consider the existence of these toxins in mollusc from non-EU locations and in seafood formulations commercialized as dietary products, so that all these products could constitute a new risk for consumers since the demand of food ingredients from marine environment has increased in the latest years [18]. Seafood as a dietary component has many human health benefits and many are connected to the consumption of important omega- 3 fatty acids, but also those food supplements based on mussels' formulations could have phycotoxins. The most common marine food supplements are based on fish (hake, trout, tuna, etc.), freshwater microalgae (Haematococcus pluvialis, Chlorella vulgaris, etc.,), macroalgae (Fucus vesiculosus, Cystoseira osmundace), cyanobacteria (Arthrospira platensis, Arthrospira maxima, etc.), and molluscs (Perna canaliculus) and they are marketed in dose form including capsules, tablets, or pills [19-21]. Marine food supplements are legislated as foods and thus, the supplier who place the product on the market has the responsibility for guaranteeing the safety of these products [22]. In Europe, although benefits of food supplements have to be supported by scientific evidence and the EFSA approval, they are not subjected to pharmacovigilance as with medicines and they do not require the same quality and homogeneity among batches [23]. For this reason and because of the increase of emerging toxin detection worldwide, it is convenient to study the contamination level of lipophilic toxins in marine dietary products.

In this study, we investigate the presence of lipophilic marine toxins in both, molluscs from non-EU locations (New Zealand, Chile, SouthEast Pacific, and Vietnam) but commercialized in Europe and marine food supplements. The aim is to know the toxin profile, their levels, and if they constitute a new risk to human health. Despite CI toxin group do not pose an official method for its detection, EFSA recommends the development and optimization of LC-MS/MS methods for the analyses of CIs. Figure 1 shows the structure of the main compounds representatives of each toxin group analyzed in this study, YTX, AZA-1, PTX-2, OA, 13-desmethyl spirolide C (SPX-13) and pinnatoxin G (PnTX-G). 


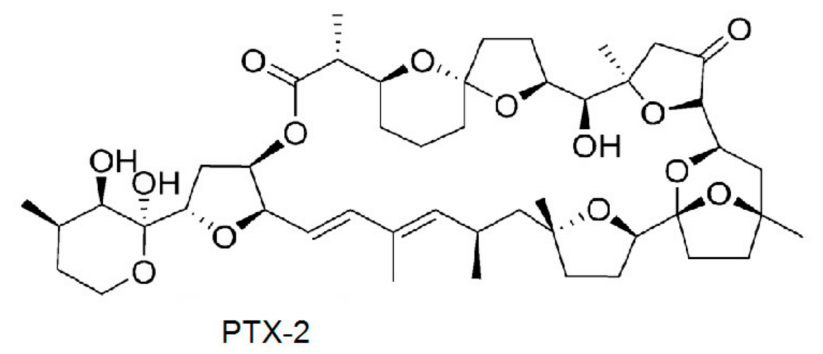

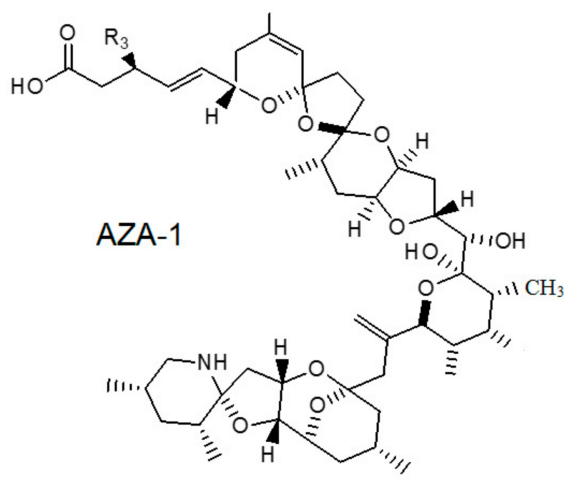

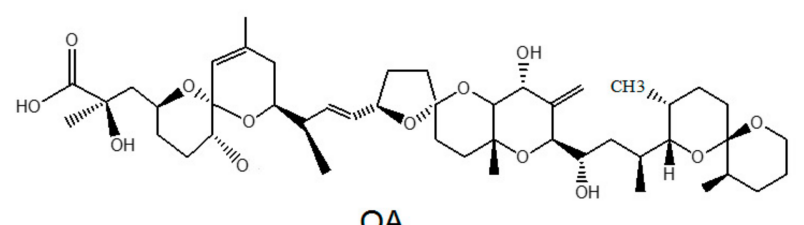

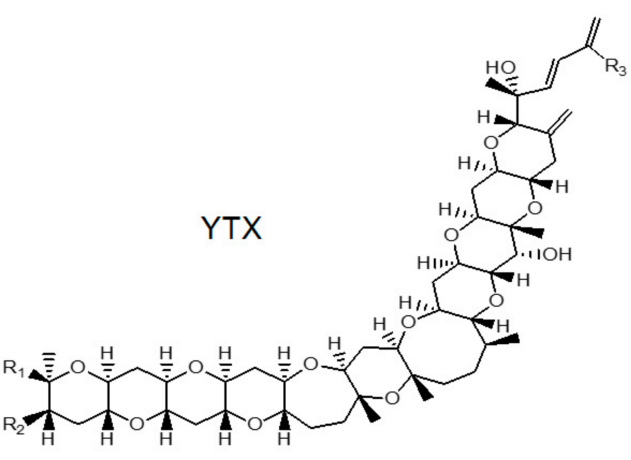

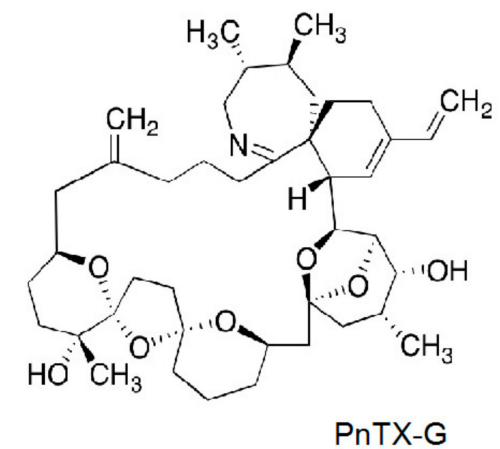

Figure 1. Structure of pectenotoxin-2 (PTX-2), azaspiracid-1 (AZA-1), okadaic acid (OA), yessotoxin (YTX), 13-desmethyl spirolide C (SPX-13), and pinnatoxin-G (PnTX-G).

\section{Results}

\subsection{Analysis of Lipophilic Marine Toxins in Molluscs}

The availability of certified reference standard PnTX-G has allowed it to be included in the EU-Harmonized Standard Operating Procedure (SOP) together with SPXs and the other toxins currently legislated. Figure $2 \mathrm{~A}$ shows the chromatogram of the standard PnTX-G $\left(\mathrm{C}_{42} \mathrm{H}_{63} \mathrm{NO}_{7}\right)$ at a concentration of $12.5 \mathrm{ng} / \mathrm{mL}$ in methanol. Mass spectrometry detection was operated in positive mode and the product ion spectra of $[\mathrm{M}+\mathrm{H}]^{+}$ions obtained for $\mathrm{m} / \mathrm{z} 694.4$ at three different collision energies (CE) are shown in Figure 2B (CE $40 \mathrm{eV})$, Figure 2C (CE $54 \mathrm{eV})$, and Figure 2D (CE $60 \mathrm{eV})$. Fragmentation pathways are in concordance with those previously reported $[11,13,24]$ in which the $\mathrm{m} / \mathrm{z}$ 164.1 fragment ion $\left(\mathrm{C}_{11} \mathrm{H}_{18} \mathrm{~N}^{+}\right)$is also common for some SPXs, including SPX-13, 13,19-didesmethyl spirolide C (SPX-13,19), spirolide C (SPX-C), spirolide-D (SPX-D), spirolide H (SPX-H), and spirolide I (SPX-I). Analysis also showed fragmentation clusters at $m / z 458.3$ and $m / z 676.3$ (Figure 2D). 

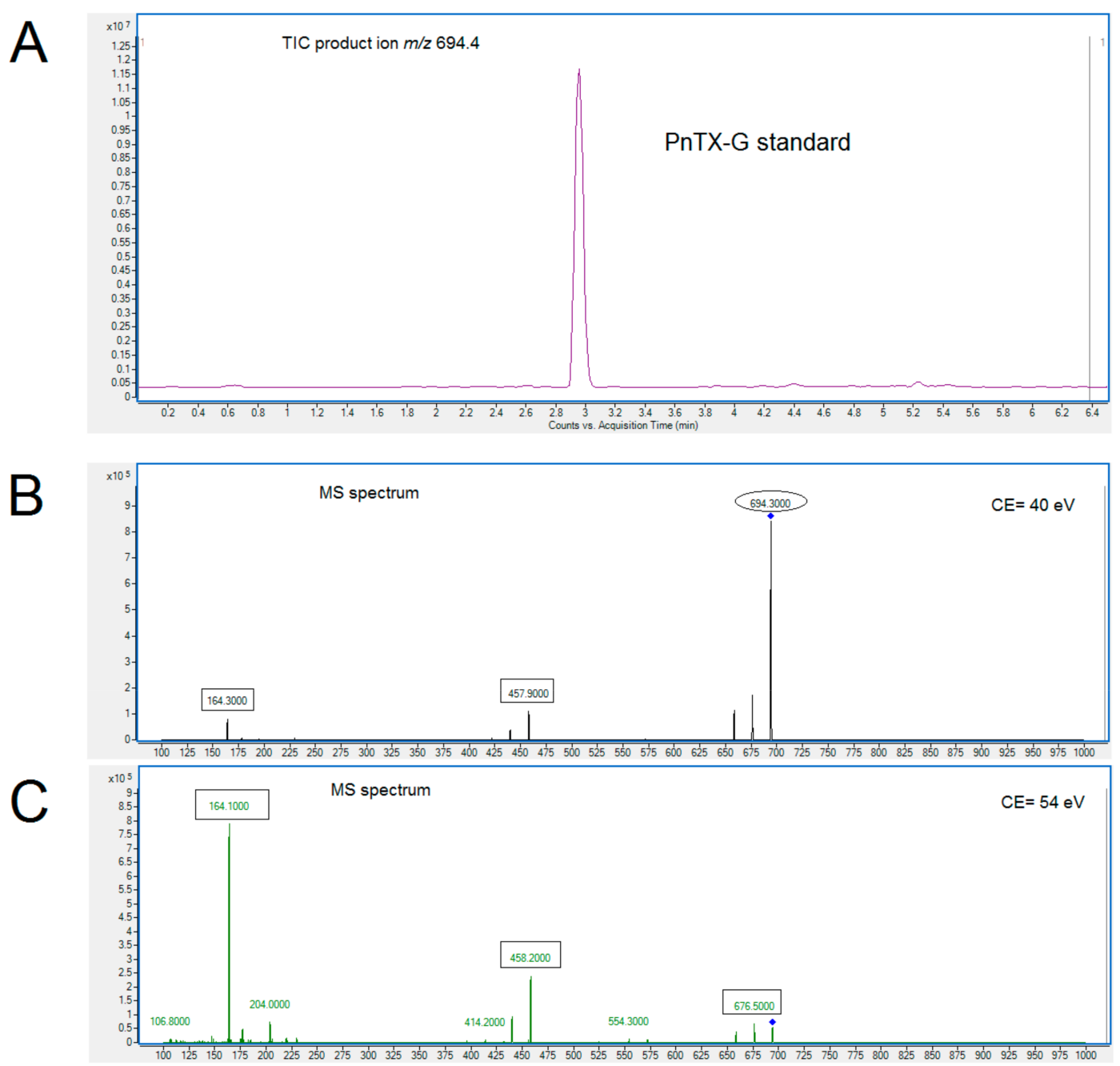

$\mathrm{D}$

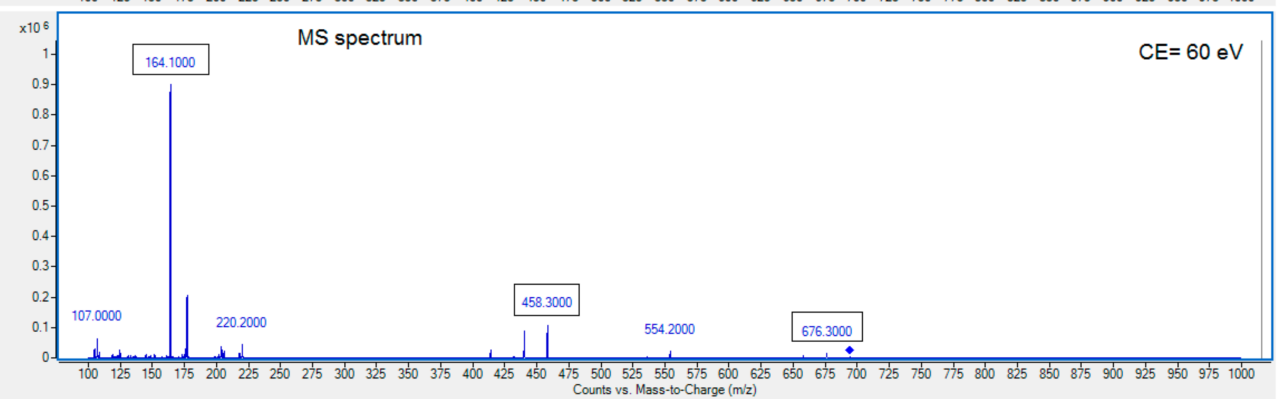

Figure 2. Chromatogram (A) and MS spectrum of PnTX-G standard at collision energy (CE) of $40 \mathrm{eV}$ (B), $54 \mathrm{eV}$ (C) and $60 \mathrm{eV}$ (D). Standard concentration: $12.5 \mathrm{ng} / \mathrm{mL}$.

Molluscs, Mytilus chilensis (M. chilensis), Tawera gayi (T. gayi) and Meretrix lyrate (M. lyrate) were analyzed with the EU-Harmonized Standard Operating Procedure (SOP) for the determination of regulated lipophilic toxins (OA, DTX-1, DTX-2, YTX, 45 OH-YTX, HomoYTX, 45 OH-HomoYTX, PTX-1, PTX-2, AZA-1, AZA-2, and AZA-3) [25] and including SPX-13, 13,19-didesmethyl spirolide C (SPX-13,19), 20-methyl spirolide C (SPX-20G) and PnTX-G. The MS transitions used in the multiple reaction monitoring (MRM) method for each toxin are indicated in Material and method section. Figure 3 shows the chromatograms from the analysis of lipophilic marine toxins. Results evidenced the presence of PnTX-G (RT = $3 \mathrm{~min}$ ) in all samples from brand A (Figure 3A) and brand B (Figure 3B) of M. chilensis. PnTXs, produced by Vulcanodinium rugosum dinoflagellate, have been detected in seafood from the Mediterranean Sea in 2013 and 2018 [10,24] and in the Atlantic coast of Spain last year [11-13]. 
These results confirm also the presence of these toxins in mussels from Chile. Chromatograms from T. gayi shows the presence of AZA-2 and PTX-2 (Figure 3C). The limits of detection (LODs) were $0.1 \mu \mathrm{g} / \mathrm{kg}$ for OA, DTX-1, DTX-2, PTX-1, and PTX-2; $0.3 \mu \mathrm{g} / \mathrm{kg}$ for AZA-1, AZA-2, and AZA-3; $1.2 \mu \mathrm{g} / \mathrm{kg}$ for YTXs; and $0.1 \mu \mathrm{g} / \mathrm{kg}$ for SPX-13, SPX-13,19, and PnTX-G. The limits of quantification (LOQs) were: $0.3 \mu \mathrm{g} / \mathrm{kg}$ (OA, DTXs and PTXs), $0.9 \mu \mathrm{g} / \mathrm{kg}$ (AZAs), $3.6 \mu \mathrm{g} / \mathrm{kg}$ (YTXs), $0.3 \mu \mathrm{g} / \mathrm{kg}$ (SPXs), and $0.4 \mu \mathrm{g} / \mathrm{kg}$ (PnTX-G). Table 1 collects the quantification for each toxin present in the samples upper the LOQs. Levels were low, up to $4.00 \mu \mathrm{g} / \mathrm{kg}, 4.33 \mu \mathrm{g} / \mathrm{kg}$, and $10.88 \mu \mathrm{g} / \mathrm{kg}$ for PnTX-G, AZA-2, and PTX-2, respectively, and no other toxin was detected under LOQs. The signal suppression/ enhancement (SSE) value because of the matrix was $94.2 \%, 40.5 \%$, and $65.0 \%$ for PTX-2, AZA-2, and PnTX-G, respectively. For three toxins, there was a negative effect which entailed a suppression of signal. To express the content of each toxin group as $\mu \mathrm{g}$ AZA equivalent (eq) $/ \mathrm{kg}$ or $\mu \mathrm{g}$ PTX eq $/ \mathrm{kg}$, the individual content of AZA-2 and PTX-2 was multiplied by the TEFs provided by EFSA which are 1.8 and 1 for AZA-2 and PTX-2, respectively.

A

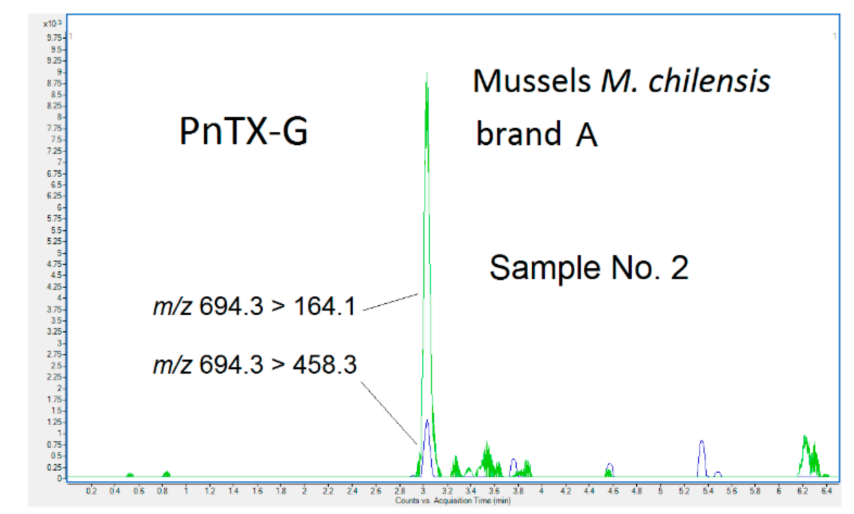

B
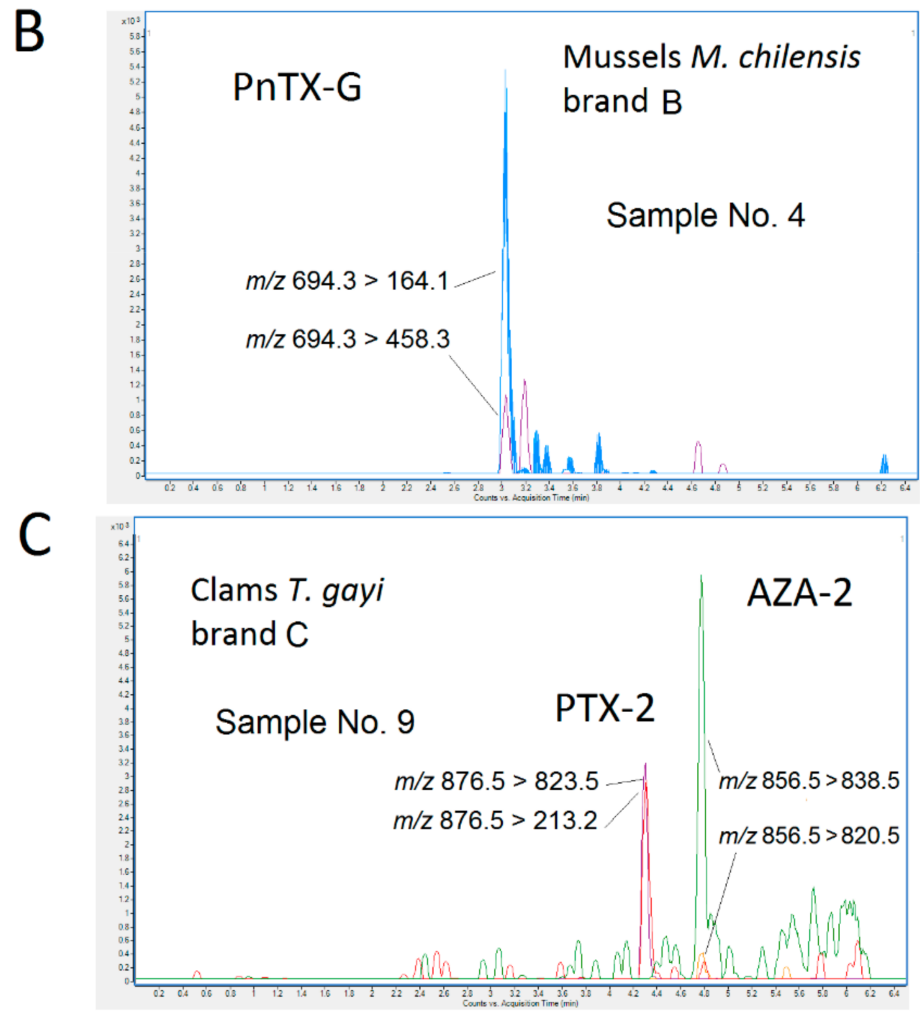

Figure 3. Multiple reaction monitoring (MRM) chromatograms of Mytilus chilensis (M. chilensis) brand A (A) and band B (B) and Tawera gayi brand C (C). 
Table 1. Concentration of PnTX-G in Mytilus chilensis mussels from Chile and AZA-2 and PTX-2 in Tawera gayi clams from Southeast Pacific.

\begin{tabular}{|c|c|c|c|c|c|c|c|}
\hline No. & Species & Brand & $\begin{array}{c}\text { AZA-2 } \\
(\mu \mathrm{g} / \mathrm{kg})\end{array}$ & $\begin{array}{c}\mu \mathrm{g} \text { AZA } \\
\text { eq/kg }\end{array}$ & $\begin{array}{c}\text { PTX-2 } \\
(\mu \mathrm{g} / \mathrm{kg})\end{array}$ & $\begin{array}{c}\mu \mathrm{g} \text { PTX } \\
\text { eq/kg }\end{array}$ & $\begin{array}{c}\text { PnTX-G } \\
(\mu \mathrm{g} / \mathrm{kg})\end{array}$ \\
\hline 1 & Mytilus chilensis & $\mathrm{A}$ & $\sim$ & $\sim$ & $\sim$ & $\sim$ & 2.9 \\
\hline 2 & Mytilus chilensis & $\mathrm{A}$ & $\sim$ & $\sim$ & $\sim$ & $\sim$ & 5.2 \\
\hline 3 & Mytilus chilensis & A & $\sim$ & $\sim$ & $\sim$ & $\sim$ & 4 \\
\hline 4 & Mytilus chilensis & B & $\sim$ & $\sim$ & $\sim$ & $\sim$ & 3.1 \\
\hline 5 & Mytilus chilensis & B & $\sim$ & $\sim$ & $\sim$ & $\sim$ & 3 \\
\hline 6 & Mytilus chilensis & B & $\sim$ & $\sim$ & $\sim$ & $\sim$ & 3.2 \\
\hline 7 & Tawera gayi & $\mathrm{C}$ & 4.09 & 7.36 & 4.41 & 4.41 & $\sim$ \\
\hline 8 & Tawera gayi & $\mathrm{C}$ & 4.33 & 7.79 & 10.88 & 10.88 & $\sim$ \\
\hline 9 & Tawera gayi & $\mathrm{C}$ & 4.25 & 7.65 & 5.84 & 5.84 & $\sim$ \\
\hline 10 & Meretrix lyrata & $\mathrm{B}$ & $\sim$ & $\sim$ & $\sim$ & $\sim$ & $\sim$ \\
\hline 11 & Meretrix lyrata & B & $\sim$ & $\sim$ & $\sim$ & $\sim$ & $\sim$ \\
\hline 12 & Meretrix lyrata & B & $\sim$ & $\sim$ & $\sim$ & $\sim$ & $\sim$ \\
\hline
\end{tabular}

\subsection{Analysis of Lipophilic Marine Toxins in Dietary Supplements}

Afterwards, dietary supplements were analyzed by UPLC-MS/MS. Toxins were extracted with two solvents, methanol (extraction 1) and methanol:water (extraction 2) explained in Material and methods section. Using both extraction methods, results showed the existence of the emerging toxin SPX-13 in 6 out of 9 samples analyzed after both extractions and no other lipophilic toxins were found. Comparing extraction methods, better results were obtained for the extraction 2 in which the percentage of water employed was the same than naturally is present in fresh mussels, which is $82 \%$ [26]. SPX-13 recovery for the extraction 2 was $98.3 \% \pm 1$.4. Figure 4 shows the chromatograms of the food supplements of Perna canaliculus (P. canaliculus) where the emerging toxin SPX-13 was identified in brand D (Figure 4A) and brand $\mathrm{F}$ (Figure 4B). These chromatograms correspond to samples extracted with method 2 and they were compared with the standard (Figure 4C), whose ion ratios were reproducible. From our knowledge, this is the first report of spirolides in mussel-based food supplements. SPX-13 originated by the marine dinoflagellate Alexandrium ostenfeldii or Alexandrium peruvianum $[27,28]$ and is the most common analogue of SPXs.

After identification, SPX-13 was quantified in all samples and amounts are shown in Table 2. Levels ranged from 33.2 to $97.9 \mu \mathrm{g} / \mathrm{kg}$. Quantification was determined by an external standard calibration and considering the matrix effect which were calculated using matrix in the absence of toxins as a blank sample. Linearity was assessed by calibration curves (nine points) prepared in both methanol and matrix within the range of $0.1 \mathrm{ng} / \mathrm{mL}$ to $25 \mathrm{ng} / \mathrm{mL}$, obtaining a proper adjusted linear regression in both cases $\left(r^{2} \geq 0.998\right)$ (Figure 5). The SSE value due to the matrix was $97.5 \%$, so there was a negative effect which entailed a suppression of signal $(-2.5 \%)$. 
Table 2. Concentration of SPX-13 in the food supplements, green lipped mussels' power.

\begin{tabular}{cccc}
\hline No. & Species & Brand & SPX-13 $(\boldsymbol{\mu g} / \mathbf{k g}$ Dry Product) \\
\hline 13 & Perna canaliculus & D & 97.9 \\
14 & Perna canaliculus & D & 90.86 \\
15 & Perna canaliculus & D & 85.6 \\
16 & Perna canaliculus & E & $<\mathrm{LOQ}$ \\
17 & Perna canaliculus & E & $<\mathrm{LOQ}$ \\
18 & Perna canaliculus & E & $<\mathrm{LOQ}$ \\
19 & Perna canaliculus & F & 39.14 \\
20 & Perna canaliculus & F & 33.2 \\
21 & Perna canaliculus & F & 33.5 \\
\hline \multicolumn{4}{c}{ Limit of quantitation $(\mathrm{LOQ}, \mathrm{SPX}-13)=13.4 \mu \mathrm{g} / \mathrm{kg}}$.
\end{tabular}

A

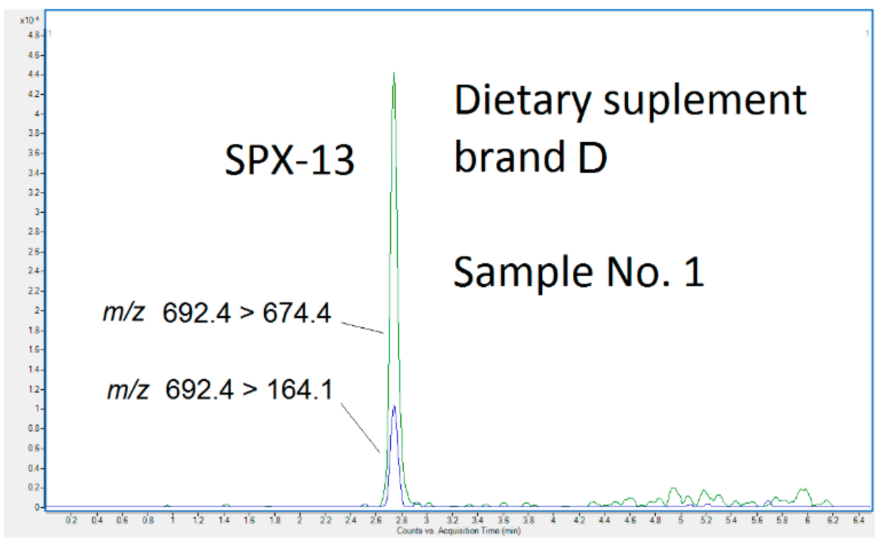

B
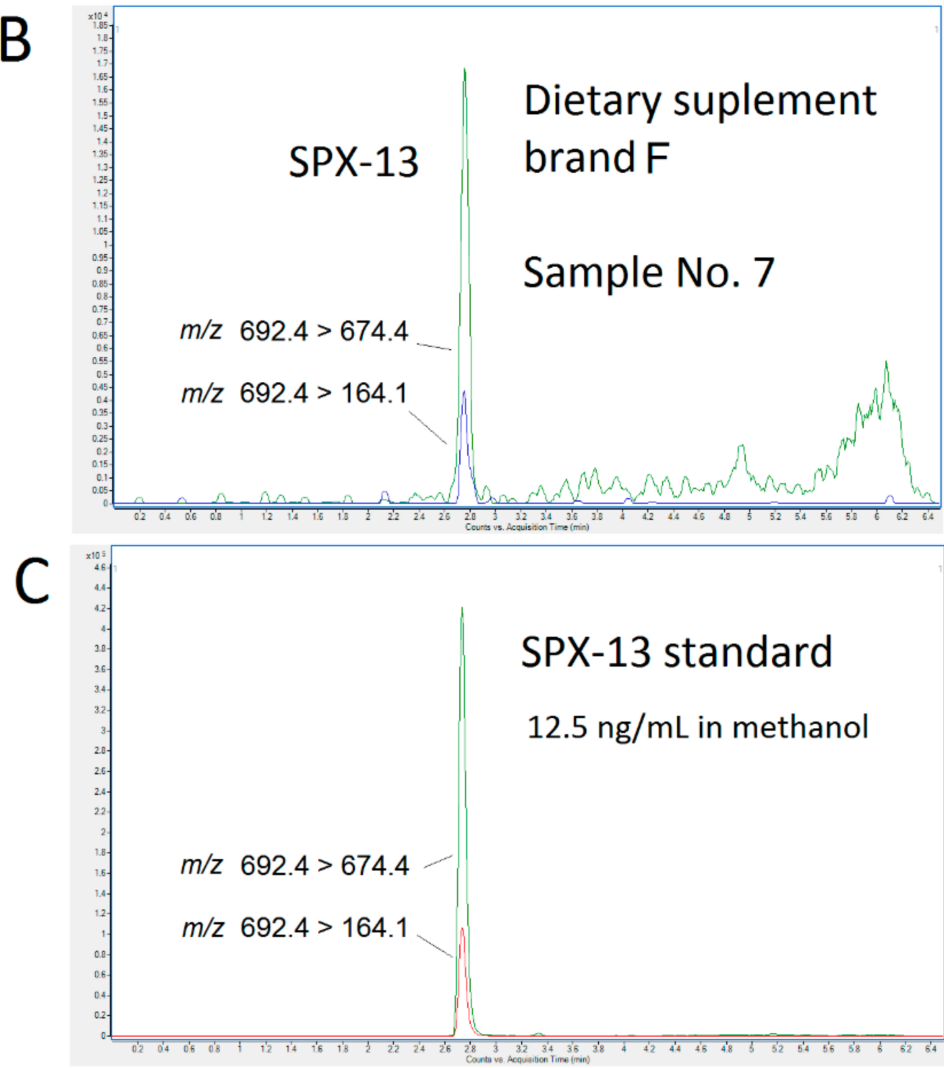

Figure 4. Multiple reaction monitoring (MRM) chromatograms of green lipped mussel powder (Perna canaliculus) brand D (A) and band F (B) and standard of 13-desmethyl spirolide C (SPX-13) (C). 

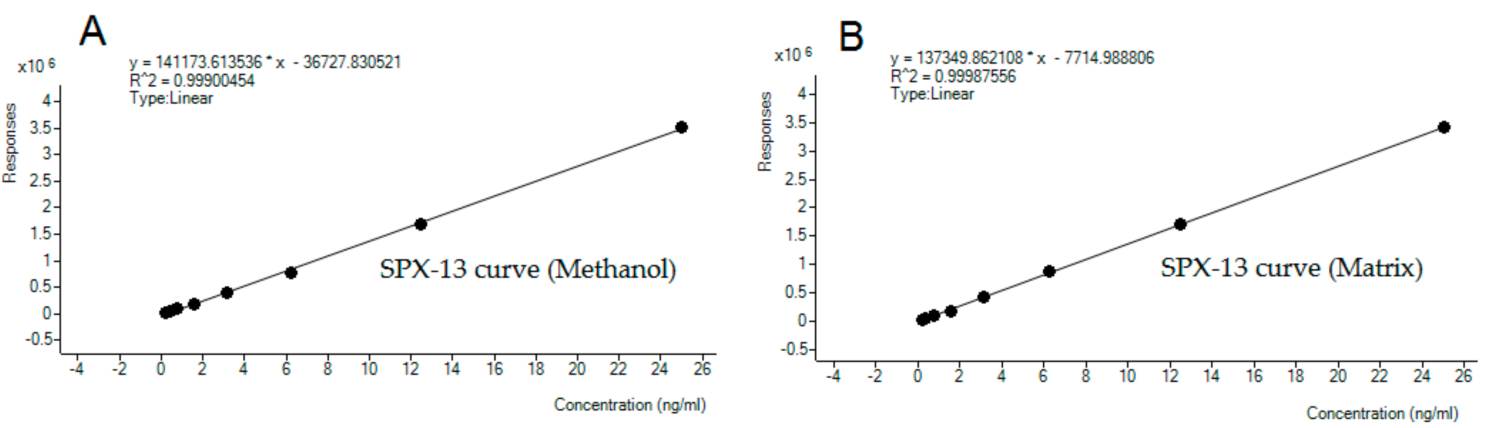

Figure 5. Calibration curves for spirolide 13-desmethyl spirolide C (SPX-13) in methanol (A) and in matrix (the powder from the dietary supplements of green lipped mussels) (B) in the range $0.19-25 \mathrm{ng} / \mathrm{mL}$.

Because the CIs consist of a large number of molecules, mainly without commercially available standards, and considering the occurrence of different analogues of PnTXs worldwide and SPX-13 in the food supplements, we also considered the possible existence of other CIs different from those first analyzed in the samples. LC-MS/MS methods are based on a targeted screening that seeks to find a list of known compounds, while missing other unknown toxic compounds that could be present in the sample. Moreover, it seems probable that PnTX-G is the precursor of PnTX-A, PnTX-B, and PnTX-C due to metabolic and hydrolytic transformations in molluscs [29]. LC-MS/MS methods are based on a targeted screening that seeks to find a list of known compounds, while missing other unknown toxic compounds that could be present in the sample. Thus, dietary supplements and molluscs were re-analyzed using a MS method including transitions for a wide range of CIs for which standards are not available. Transitions are included in material and methods section (Table 3). The screening of CIs by UPLC-MS/MS showed that no other analogues were in the samples.

Table 3. Food samples and origin. Amount obtained are also included.

\begin{tabular}{cccccc}
\hline No. & Food Product & Species & Origin & Brand & Sample Amount \\
\hline 1 & Cooked Mussels & Mytilus chilensis & Chile & $\mathrm{A}$ & $360 \mathrm{~g}$ \\
2 & Cooked Mussels & Mytilus chilensis & Chile & $\mathrm{A}$ & $360 \mathrm{~g}$ \\
3 & Cooked Mussels & Mytilus chilensis & Chile & $\mathrm{A}$ & $360 \mathrm{~g}$ \\
4 & Cooked Mussels & Mytilus chilensis & Chile & $\mathrm{B}$ & $275 \mathrm{~g}$ \\
5 & Cooked Mussels & Mytilus chilensis & Chile & $\mathrm{B}$ & $275 \mathrm{~g}$ \\
6 & Cooked Mussels & Mytilus chilensis & Chile & $\mathrm{B}$ & $275 \mathrm{~g}$ \\
7 & clams & Tawera gayi & SouthEast Pacific & $\mathrm{C}$ & $600 \mathrm{~g}$ \\
8 & clams & Tawera gayi & SouthEast Pacific & $\mathrm{C}$ & $600 \mathrm{~g}$ \\
9 & clams & Tawera gayi & SouthEast Pacific & $\mathrm{C}$ & $600 \mathrm{~g}$ \\
10 & clams & Meretrix lyrata & Vietnam & $\mathrm{B}$ & $1000 \mathrm{~g}$ \\
11 & clams & Meretrix lyrata & Vietnam & $\mathrm{B}$ & $1000 \mathrm{~g}$ \\
12 & clams & Meretrix lyrata & Vietnam & $\mathrm{B}$ & $1000 \mathrm{~g}$ \\
13 & Green lipped mussels powder & Perna canaliculus & New Zealand & $\mathrm{D}$ & $101 \mathrm{~g}$ \\
14 & Green lipped mussels powder & Perna canaliculus & New Zealand & $\mathrm{D}$ & $101 \mathrm{~g}$ \\
15 & Green lipped mussels powder & Perna canaliculus & New Zealand & $\mathrm{D}$ & $101 \mathrm{~g}$ \\
16 & Green lipped mussels powder & Perna canaliculus & No information & $\mathrm{E}$ & $500 \mathrm{mg}$ \\
17 & Green lipped mussels powder & Perna canaliculus & No information & $\mathrm{E}$ & $500 \mathrm{mg}$ \\
18 & Green lipped mussels powder & Perna canaliculus & No information & $\mathrm{E}$ & $500 \mathrm{mg}$ \\
19 & Green lipped mussels powder & Perna canaliculus & No information & $\mathrm{F}$ & $45 \mathrm{~g}$ \\
20 & Green lipped mussels powder & Perna canaliculus & No information & $\mathrm{F}$ & $45 \mathrm{~g}$ \\
21 & Green lipped mussels powder & Perna canaliculus & No information & $\mathrm{F}$ & $45 \mathrm{~g}$ \\
\hline
\end{tabular}

\section{Discussion}

This study shows the first evidence of the newly discovered toxin PnTX-G in mussels M. chilensis and SPX-13 in dietary supplements of mussels P. canaliculus. PnTXs were first detected in viscera of 
Japanese Pinna muricata in 1995 [30] and then, they expanded to other areas and species. These toxins were found in Pacific oysters (Crassostrea gigas) and razor fish (Pinna bicolor) from South Australia and Northland New Zealand [31,32], mussels from Norway [7], Canada [33], and clams (Venerupis decussata) from France [24]. Recently, PnTXs were also detected in mussels (M. galloprovincialis) from the Atlantic Coast of Spain [11-13] and in other countries from the Atlantic and Mediterranean coastline including Scotland, Northern Ireland, Ireland, Italy, Norway, and Portugal [34]. Concentrations of PnTXs in shellfish are generally low, however, PnTX-G was found to reach the concentration of $1200 \mu \mathrm{g} / \mathrm{kg}$ in mussels collected in the coast of France [24,29]. Lamas et al. (2019) found that the maximum PnTX-G levels in the South of Europe are during winter [11]. However, Arnich et al. (2020) showed that PnTX-G peaks were observed between June and September from molluscs collected from the French Mediterranean coast between 2013 and 2017 [14]. Last year, because of the occurrence of PnTXs in France, the French Agency for Food, Environmental and Occupational Health and Safety has developed a scientific opinion regarding the presence of PnTXs in shellfish, setting an acceptable contamination value of $23 \mu \mathrm{g}$ PnTX-G/kg (total meat). Thus, a possible risk for human consumers occurs when bivalves accumulate toxins higher than this value as a result of ingesting the toxic microalgae [14]. In the present study, PnTX-G reached a maximum of $5.25 \mu \mathrm{g} / \mathrm{kg}$ (M. chilensis), much lower than the proposed level. A very recent study has allowed to stablish an oral LD 50 for PnTx-G of $208 \mu \mathrm{g} / \mathrm{kg}$ and a provisional No Observed Effect Level (NOEL) of $120 \mu \mathrm{g} / \mathrm{kg}$ [35].

Clams T. gayi showed AZA-2 and PTX-2 in small quantities. No trace levels neither AZA-1 nor AZA-3 were detected. These results agree with others in which AZA-2 was the most abundant or unique analog among the three (AZA-1, AZA-2, AZA-3) monitored [12,36]. In the present study, clams T. gayi from the SouthEast Pacific exhibited up to $4.33 \mu \mathrm{g} / \mathrm{kg}$ of AZA-2, levels comparable to those found in mussels from the Atlantic coast of Spain $(1.8-3 \mu \mathrm{g} / \mathrm{kg})[12,36]$. Although AZA-1 was the predominant analogue in Chilean mussels, AZA2 predominated in Pacific scallop (Argopecten purpuratus) from the same country [37]. From a safety point of view, toxicology evaluations of AZA-2 indicate this analog is less toxic than AZA-1 [38]. The estimation of AZAs lowest observed adverse effect level (LOAEL) was established at $1.9 \mu \mathrm{g}$ AZA eq/kg body weight (b.w.) [38] and the acute reference dose (ARfD) was set at $0.2 \mu \mathrm{g} \mathrm{AZA} \mathrm{eq/kg} \mathrm{b.w.} \mathrm{[38].} \mathrm{Currently,} \mathrm{the} \mathrm{estimation} \mathrm{of} \mathrm{AZA-related} \mathrm{shellfish} \mathrm{toxicity} \mathrm{is}$ based on the quantification of AZA1-3 [1], and the TEFs extrapolated from mouse i.p. DD $_{50}$ of these three compounds, with values of 1.0, 1.8, and 1.4 for AZA-1, AZA-2, and AZA-3, respectively [38]. EFSA identified $400 \mathrm{~g}$ of shellfish meat as the high portion size to be used in the acute risk assessment of marine biotoxins [39]. It was noted that consumption of a $400 \mathrm{~g}$ portion of shellfish meat containing AZAs at the current EU limit of $160 \mu \mathrm{g}$ AZA eq $/ \mathrm{kg}$ shellfish meat would result in a dietary exposure of $64 \mu \mathrm{g}$ AZA eqs. For a $60 \mathrm{~kg}$ adult this is approximately $1 \mu \mathrm{g}$ AZA eq/kg b.w. In order for a $60 \mathrm{~kg}$ adult to not exceed the ARfD, a $400 \mathrm{~g}$ portion of shellfish should not contain more than $12 \mu \mathrm{g}$ AZA eq, i.e., $30 \mu \mathrm{g}$ AZA eq/kg shellfish meat [39], much higher than the amount found in the present study. In 2018, more proper TEFs from oral $\mathrm{LD}_{50}$ results (in mice) were proposed, resulting in 1.0, 0.7, and 0.5 for AZA-1, AZA-2, and AZA-3 respectively [40]. These TEFs seems more adequate since considering the potential human exposure by oral route, AZAs TEFs should be calculated by comparative oral toxicity data [40]. Considering these new TEFs, the amount of total AZA in T. gayi is lower than $3 \mu \mathrm{g}$ eq AZA/kg.

Similarly, PTX-2 levels in T. gayi (4.41-10.88 $\mu \mathrm{g} / \mathrm{kg}$ ) were also low compared to other Pacific bivalves $(82.0 \mu \mathrm{g} / \mathrm{kg})$ [41]. The toxicological database for PTX-group toxins is limited and comprises mostly studies on their acute toxicity in mice. There are no reports on adverse effects in humans associated with PTX-group toxins. PTX-2 was acutely toxic to mice by i.p. injection $\left(\mathrm{LD}_{50}=219 \mu \mathrm{g} / \mathrm{kg}\right)$ and it was not overtly toxic to mice by the oral route at doses up to $5000 \mu \mathrm{g} / \mathrm{kg}$. [42]. EFSA had proposed a TEF value of 1 for PTX-1 and PTX-2 [43]. Although the oral toxicity is not well defined, it was stablished a LOAEL of $250 \mu \mathrm{g} / \mathrm{kg}$ b.w. and an ARfD of $0.8 \mu \mathrm{g}$ PTX eq/ $/ \mathrm{kg}$ b.w. Thus, for a $60 \mathrm{~kg}$ adult to avoid exceeding the ARfD of $0.8 \mu \mathrm{g}$ PTX eq/ $\mathrm{kg}$ b.w., a $400 \mathrm{~g}$ portion of shellfish should not contain more than $48 \mu \mathrm{g}$ PTX eq corresponding to $120 \mu \mathrm{g}$ PTX-2 eq/kg shellfish meat [43]. 
In Asian molluscs, several combinations of lipophilic marine toxins were reported, including OA/YTX, OA/PTX-2, YTX/OA, PTX-2/OA, PTX-2/GYM, GYM/PTX-2 [44], and also AZA-2/PTX-2 [45]. It appears that $\mathrm{OA}$ is the most often recorded lipophilic toxin in mixtures, as well as the predominant toxin in the mixture [44]. Toxicological studies reporting the effects of the co-association AZA-2/PTX-2 were not found in the literature.

SPXs were discovered in Canadian mussels in the early 1990s [46] and nowadays are distributed worldwide, not only in edible species (clams, cockles), but also in other species which have a significant role in the food-chain, such as gastropods (Gibbula. umbilicalis, Nucella. lapillus, Patella. intermedia, Monodonta sp.) and starfish (Marthasterias. glacialis) [47]. It was not recorded, neither the presence of SPXs in dietary supplements nor in P. canalicus mussels before. Marine food supplements constitute an important part of the global market and are produced from different sources that provide a multitude of bioactive molecules such us proteins, unsaturated essential fatty acids, vitamins, minerals, carotenoids, polysaccharides $[18,20,48]$. Particularly, green lipped mussels' powder is known for their therapeutic use in the rheumatoid or osteoarthritis treatment [49] with significant anti-inflammatory activity because of the content of omega-3 polyunsaturated fatty acids [50]. This dietary food supplement is marketed globally, easily available and announced as beneficial for health. Nevertheless, dietary products could also lead to potential toxic risks related to the contamination by toxins [51]. This is the first report of an emerging marine CI toxin found in mussel-based supplements. However, a variety of other toxic substances has been recorded in marketed samples of food supplements considering both scientific literature and Rapid Alert System for Food and Feed notifications [51]. These contaminants include metals, polychlorinated biphenyls (PCBs), mycotoxins, and cyanotoxins [51]. There is no information regarding the presence of CIs in fresh P. canaliculus. Instead, it was reported the presence of YTXs (16-32 $\mu \mathrm{g} / \mathrm{kg})$ and PTX-2 (2-15 $\mu \mathrm{g} / \mathrm{kg})$ [52]. SPX-13 in food supplements were at levels up to $97.9 \mu \mathrm{g} / \mathrm{kg}$ and the content of $500 \mathrm{mg}$ of concentrated green mussel was provided in each capsule. It was viable to design a proper extraction procedure with $97 \%$ of toxin recovery and able to quantify SPX-13 in the range of $13.4-427.35 \mu \mathrm{g} / \mathrm{kg}$ with almost inexistent matrix effect.

The availability of blank matrix is an important issue when developing detection methods by LC-MS/MS since majority of molluscs already have marine toxins naturally. This could be solved, introducing internal standards that behave similarly to the analogues of interest analyzed. Also, current MS/MS detection methodology for marine toxins are based on a defined target list of toxins and are not usually appropriate for the identification of unknown compounds [53]. To guarantee the consumers' safety, food quality assurance would have to detect the presence of toxic unknown compounds which include newly discovered toxins, the identification of known toxins in areas and species where they had not been recorded before. When assessing the associated risk for human health because of the geographical expansion of marine toxins, there is an urgent need for robust analytical methodologies that can detect a wide range of known or emerging toxins in different matrix.

\section{Materials and Methods}

\subsection{Molluscs and Dietary Supplements Acquisition and Sample Preparation}

A total of 21 marine food products were purchased during November and December 2019. Product type, origin, and amount obtained from the market are described in Table 3. They were from four locations (New Zealand, Chile, SouthEast Pacific and Vietnam) and belonged to six commercial brands (called A, B, C, D, E, and F). Samples 1-6 are frozen mussels (M. chilensis) and samples 6-12 are frozen clams (T. gayi and M. lyrate), all purchased in a local market in Lugo (Spain). Samples 13-21 are green lipped mussels powder ( $P$. canaliculus) and they were obtained by three different EU distributors. Samples from the same brand come from the same batch and species (and locations) were chosen at random, since they are frequent products available in local markets.

Once in the laboratory meat molluscs were defrosted, removed from shell and homogenized (Ultra Turrax ${ }^{\mathrm{TM}}$, Staufen, Germany), stored in bags at $-20^{\circ} \mathrm{C}$, and preserved from oxygen and light. 
Each sample was a homogenate of the tissue of 15 individual mollusc (100 g approx.). Food supplement capsules were opened, and the powder content was passed to a $45 \mathrm{~mL}$ empty tube. Each sample was a homogenate of 40 capsules content (20 $\mathrm{g}$ approx.)

\subsection{Chemicals}

Acetonitrile, methanol, sodium hydroxide, and hydrochloric acid were obtained from Panreac (Barcelona, Spain). Formic acid was purchased from Merck (Darmstadt, Germany) and ammonium formate was from Fluka (Sigma-Aldrich, Madrid, Spain). All solvents were of HPLC or analytical grade and water was obtained from a water purification system (Milli-Q, Millipore, Madrid, Spain). Certified reference materials were provided by Cifga (Lugo, Spain): dinophysistoxin-1 (DTX-1 $8.08 \pm 0.41 \mu \mathrm{g} / \mathrm{g}$ ), dinophysistoxin-2 (DTX-2 $2.54 \pm 0.14 \mu \mathrm{g} / \mathrm{g}$ ), okadaic acid (OA $24.92 \pm 1.82 \mu \mathrm{g} / \mathrm{g}$ ), tessotoxin (YTX 7.42 $\pm 0.49 \mu \mathrm{g} / \mathrm{g}$ ), 1a-homoyessotoxin (homo-YTX $7.68 \pm 0.44 \mu \mathrm{g} / \mathrm{g}$ ), azaspiracid-1 (AZA-1 $1.36 \pm 0.07 \mu \mathrm{g} / \mathrm{g}$ ), azaspiracid-2 (AZA-2 $1.33 \pm 0.11 \mu \mathrm{g} / \mathrm{g}$ ), and azaspiracid-3 (AZA-3 $1.30 \pm 0.09 \mu \mathrm{g} / \mathrm{g}), 13-$ desmethyl spirolide C (SPX-13, $7.29 \pm 0.36 \mu \mathrm{g} / \mathrm{mL}), 13,19$-didesmethyl spirolide C (SPX-13,19, $7.51 \pm 0.38 \mu \mathrm{g} / \mathrm{mL})$, and 20-methyl spirolide G (SPX-20, $7.01 \pm 0.61 \mu \mathrm{g} / \mathrm{mL}$. Certified calibration solutions for pinnatoxin-G (PnTX-G, $2.43 \pm 0.11 \mu \mathrm{g} / \mathrm{g}$ ) and for pectenotoxin-2 (PTX-2, $5.58 \pm 0.16 \mu \mathrm{g} / \mathrm{g}$ ) were purchased from The Institute for Marine Biosciences, National Research Council, Halifax, NS, Canada.

\subsection{Toxin Extraction}

Mollusc were extracted following the EU-Harmonized Standard Operating Procedure (SOP) for the determination of lipophilic marine biotoxins in molluscs by LC-MS/MS [25]. All bivalves were extracted according the procedure from Section 6.2 of the SOP; the Annex C was not applied for cooked samples. The amount of $2.00 \mathrm{~g}$ of tissue homogenate were weighed into a centrifuge tube. Then, $9 \mathrm{~mL}$ of methanol was added to it and the sample was homogenized by vortex mixing during $3 \mathrm{~min}$. Afterwards, the samples were centrifuged $(3700 \mathrm{rpm} \times 10 \mathrm{~min})$ at $20{ }^{\circ} \mathrm{C}$ and the supernatant was transferred to a $20-\mathrm{mL}$ volumetric flask. The extraction of the residual tissue pellet was repeated with another $9 \mathrm{~mL}$ of methanol using a high-speed homogenizer (T25 digital Ultra-Turrax, $\mathrm{IKA}^{\circledR}$-Werke GmbH \& Co. KG, Staufen, Germany). After centrifugation (3700 rpm $\left.\times 10 \mathrm{~min}\right)$ at $20^{\circ} \mathrm{C}$, the supernatants were combined into a final volume of $20 \mathrm{~mL}$ with methanol. The volume of $15 \mathrm{~mL}$ was concentrated to $5 \mathrm{~mL}$ to improve the sensibility of the analyses. One aliquot of $500 \mu \mathrm{L}$ was filtered through $0.22 \mu \mathrm{m}$ filter and then analyzed by LC-MS/MS. Food supplements were extracted adding methanol to the powder samples (extraction 1) or using methanol after a rehydration of the food supplements (extraction 2). For the extraction 1, $2 \mathrm{~g}$ of powder food supplement homogenate were weighed into a centrifuge tube and extracted with $9 \mathrm{~mL}$ of methanol. The extract was homogenized via vortex and then, the samples were centrifuged ( $3700 \mathrm{rpm} \times 10 \mathrm{~min}$ ) and the content was transferred to $20 \mathrm{~mL}$ volumetric flash. The extraction of the residual tissue pellet was repeated with another $9 \mathrm{~mL}$ of methanol. After centrifugation $(3700 \mathrm{rpm} \times 10 \mathrm{~min})$, the supernatants were combined into a final volume of $20 \mathrm{~mL}$ with methanol. The extraction 2 was performed in two steps. First, an amount of $1.64 \mathrm{~mL}$ of water was added to $0.36 \mathrm{~g}$ of power food supplement in order to have a humid mussel extract with the same water content as the fresh mollusc $\left(82 \pm 0.02 \mathrm{~g} \mathrm{H}_{2} \mathrm{O} / 100 \mathrm{~g}\right.$ [26]). After that, it was extracted according to extraction 1.

\subsection{UPLC-MS Analysis}

Analyses were performed by a 1290 Infinity ultra-high-performance liquid chromatography system coupled to an Agilent G6460C Triple Quadrupole mass spectrometer equipped with an Agilent Jet Stream ESI source (Agilent Technologies, Waldbronn, Germany). The toxins were separated using a column AQUITY UPLC BEH C18 $(2.1 \times 100 \mathrm{~mm}, 1.7 \mu \mathrm{m}$, Waters, Barcelona, Spain $)$ at $40{ }^{\circ} \mathrm{C}$. Mobile phase A was 100\% water and B acetonitrile-water (95:5), both containing $50 \mathrm{mM}$ formic acid and $2 \mathrm{mM}$ ammonium formate. The gradient program with a flow rate of $0.4 \mathrm{~mL} / \mathrm{min}$ was started with $30 \% \mathrm{~B}$ and then a linear gradient to $70 \% \mathrm{~B}$ in $3 \mathrm{~min}$. After an isocratic hold time linear of $1.5 \mathrm{~min}$ at $70 \% \mathrm{~B}$ 
and return to the starting conditions of 30\% B in $0.1 \mathrm{~min}$. Finally, 30\% B was kept for $1.99 \mathrm{~min}$ before the next injection. The samples in the autosampler were cooled to $4{ }^{\circ} \mathrm{C}$ and the injection volume was $5 \mu \mathrm{L}$. Source conditions were: $350{ }^{\circ} \mathrm{C}$ of drying gas temperature with $8 \mathrm{~L} / \mathrm{min}$ flow, nebulizer gas pressure of 45 psi (Nitrocraft NCLC/MS from Air Liquid, Madrid, Spain), sheath gas temperature of $400{ }^{\circ} \mathrm{C}$ and a flow of $11 \mathrm{~L} / \mathrm{min}$. The capillary voltage was set to $4000 \mathrm{~V}$ in negative mode with a nozzle voltage of $0 \mathrm{~V}$ and $3500 \mathrm{~V}$ in positive mode with a nozzle voltage of $500 \mathrm{~V}$. Analyses were performed in multiple reaction monitoring (MRM) acquisition mode, selecting two transitions per molecule. The first transition of each toxin indicated below was used for quantification and second one used as qualifier. Transitions for regulated toxins were: 45-OH-homo-YTX $(\mathrm{m} / z 1171.5>1091.5$, $m / z 1171.5>869.5), 45-\mathrm{OH}-Y T X(m / z 1157.5>1077.5, m / z 1171.5>871.5)$, Homo-YTX $(m / z 1155.5>$ 1075.5, $\mathrm{m} / \mathrm{z} 1155.5>869.4)$, YTX $(\mathrm{m} / \mathrm{z} 1141.5>1061.5, \mathrm{~m} / \mathrm{z} 1141.5>855.4)$, PTX-1 $(\mathrm{m} / \mathrm{z} 892.5>821.5, \mathrm{~m} / \mathrm{z}$ $892.5>213.2)$, PTX-2 $(\mathrm{m} / \mathrm{z} 876.5>823.5, \mathrm{~m} / \mathrm{z} 892.5>213.2)$, AZA-1 $(\mathrm{m} / \mathrm{z} 842.5>824.5, \mathrm{~m} / \mathrm{z} 842.5>806.5)$, AZA-2 $(\mathrm{m} / \mathrm{z} 856.5>838.5, \mathrm{~m} / \mathrm{z} 856.5>820.5)$, AZA-3 $(\mathrm{m} / \mathrm{z} 828.5>810.5, \mathrm{~m} / \mathrm{z} 828.5>792.5)$, OA/DTX-2 $(m / z 803.5>255.1, m / z 803.5>113.2)$, and DTX-1 $(m / z 817.5>255.1, m / z 817.5>113)$. Collision energy of each fragment are described in [12]. The MS/MS method for the screening of emerging toxins are described in Table 4. The MS/MS operated in positive ionization mode and the cell acceleration voltage (CAV) was 4 volts. Dwell was 6 for all toxins.

Table 4. MS/MS method parameters for non-regulated marine toxins. Precursor and product ions monitored $(m / z)$, collision energy $(\mathrm{CE})$ and fragmentor voltage (Frag) are included.

\begin{tabular}{ccccc}
\hline Toxin & Precursor Ion $[\mathbf{M}+\mathbf{H}]^{+}$ & Product Ion & CE & Frag \\
\hline Pinnatoxin A & 712.4 & $458.3 ; 164.1$ & $54 ; 60$ & 112 \\
Pinnatoxin-B/C & 741.5 & $458.3 ; 164.1$ & $54 ; 60$ & 112 \\
Pinnatoxin D & 782.5 & $446.3 ; 164.1$ & $54 ; 60$ & 112 \\
Pinnatoxin E & 784.5 & $446.3 ; 164.1$ & $54 ; 60$ & 112 \\
Pinnatoxin F & 766.5 & $446.3 ; 164.1$ & $54 ; 60$ & 112 \\
Pinnatoxin G & 694.5 & $458.3 ; 164.1$ & $54 ; 60$ & 112 \\
Gymnodimine A & 508.3 & $392.4 ; 490.4$ & $54 ; 40$ & 180 \\
Gymnodimine B/C & 524.4 & $488.4 ; 506.4$ & $40 ; 54$ & 180 \\
Gymnodimine D & 324.4 & $406.4 ; 504.4$ & $54 ; 40$ & 180 \\
12-methyl Gymnodimine A & 522.4 & $674.4 ; 164.1$ & $30 ; 54$ & 180 \\
13-desmethyl spirolide C & 692.4 & $660.4 ; 164.1$ & $30 ; 54$ & 149 \\
13,19-didesmethyl spirolide C & 678.4 & $688.4 ; 164.1$ & $30 ; 54$ & 152 \\
20-methyl spirolide C & 706.47 & 150.1 & 70 & 180 \\
Spirolide A & 692.5 & 150.1 & 70 & 180 \\
Spirolide B & 694.5 & $458.3 ; 164.1$ & $42 ; 54$ & 180 \\
Spirolide C & 706.5 & $458.3 ; 164.1$ & $42 ; 54$ & 180 \\
Spirolide D & 708.5 & 444.3 & 60 & 180 \\
Spirolide E & 710.5 & 444.3 & 60 & 180 \\
Spirolide F & 712.5 & $378.3 ; 164.1$ & $42 ; 54$ & 180 \\
Spirolide G & 692.5 & $402.3 ; 164.1$ & $42 ; 54$ & 180 \\
Spirolide H & 650.4 & $402.3 ; 164.1$ & $42 ; 54$ & 180 \\
Spirolide I & 652.5 & $464.3 ; 180.1$ & $42 ; 54$ & 180 \\
27-hydroxy-13,19-didesmethyl SPX-C & 694.4 & $478.4 ; 180.1$ & $42 ; 54$ & 180 \\
27-hydroxy-13-desmethyl SPX-C & 708.4 & $444.3 ; 178.1$ & $42 ; 54$ & 180 \\
\hline 19-didesmethyl SPX-C & 692.4 & & 45 \\
\hline
\end{tabular}

\subsection{Method Performance, Recovery, and Matrix Correction}

Analytical method performance assessment was performed for three days following the EU-Harmonized SOP for Lipophilic toxins [25] and the guidelines proposed by the Regulation (EC) 657/2002 [54]. The external standard calibration curves were made in methanol with nine levels in the range of $0.09 \mathrm{ng} / \mathrm{mL}$ to $25 \mathrm{ng} / \mathrm{mL}$. Linearity was assessed by the regression coefficients of the quantification curves which had to be bigger than 0.99 and the slope variation between the sets of the calibration curve which had to be lower than $25 \%$ to be considered as acceptable. Sensitivity of the 
method was evaluated with the slope of the calibration curves and with the limit of detection (LOD) and limit of quantification (LOQ) which were calculated based on an signal-to-noise ratio of 3 and 10 , respectively, using triplicate injections $(n=3)$ of standard solutions with quantities near the limits.

To address the effects of the extraction procedure and of the matrix, spiked mollusc extracts and dietary supplements (free of toxins) were used as a blank for toxin recovery and matrix correction. To calculate the signal suppression/ enhancement (SSE) factor due to the matrix, blank samples were extracted following extraction procedures described above. Nine concentration levels of each standard were diluted in toxin-free extracts (blank sample) and then it was analyzed by LC-MS/MS. The slopes of the curves were employed for calculating the SSE value according to the following equation: SSE $(\%)=100 \times$ (Slope of spiked extract curve/Slope of standards curve in solvent). If SSE value is $100 \%$, no matrix effect is observed whereas if the value is higher than $100 \%$, a positive matrix effect due to an enhancement of the ionization is observed. If this value is below $100 \%$ there is a negative effect, which entails a suppression of the signal due to ionic suppression. The corrected concentration considering the recovery and matrix effects was calculated as follows:

$$
\frac{\mu \mathrm{g} \text { toxin }}{\mathrm{kg}}=\left(\frac{\mu \mathrm{g}}{\mathrm{kg}}\right) \text { EXTERNAL CALIBRATION } \times\left(\frac{100}{\% \mathrm{R} \text { spiked extract }}\right) \times\left(\frac{100}{\% \mathrm{SSE}}\right)
$$

where: $(\mu \mathrm{g} / \mathrm{kg})$ EXTERNAL CALIBRATION is the concentration calculated by external calibration prepared in methanol with 9 levels in the range of 0.09 to $25 \mathrm{ng} / \mathrm{mL}$.

Author Contributions: Conceptualization, L.M.B., P.O.; investigation, P.O., C.V., M.C.L., and L.M.B.; methodology, A.B.-J., C.C., and P.O.; formal analyses, P.O.; supervision, P.O. and L.M.B.; funding acquisition, L.M.B. and P.O.; writing-original draft, P.O.; writing-review and editing, C.V., M.C.L., and L.M.B. All the authors participated in the proofreading of the manuscript. All authors have read and agreed to the published version of the manuscript.

Funding: The research leading to these results has received funding from the following FEDER cofunded-grants. From Conselleria de Cultura, Educación e Ordenación Universitaria, Xunta de Galicia, 2017 GRC GI-1682 (ED431C 2017/01). From European Union Interreg AlertoxNet EAPA-317-2016, Interreg Agritox EAPA-998-2018, and H2020 778069-EMERTOX. This work was also supported by the program "Juan de la Cierva 2016" (Ref. IJCI-2016-27774) from the Spanish Government.

Acknowledgments: Andrea Boente-Juncal and Celia Costas are recipients of fellowships from Ministerio de Educación, Cultura y Deporte, Spain (FPU16/07129 and FPU18/05681). Paz Otero is recipient of Postdoctoral Funding from the Ministerio de Ciencia, Innovación y Universidades, Spain (IJCI-2016-27774).

Conflicts of Interest: The authors declare no conflict of interest. The funders had no role in the design of the study; in the collection, analyses, or interpretation of data; in the writing of the manuscript, or in the decision to publish the results.

\section{References}

1. Vilariño, N.; Louzao, M.C.; Abal, P.; Cagide, E.; Carrera, C.; Vieytes, M.R.; Botana, L.M. Human Poisoning from Marine Toxins: Unknowns for Optimal Consumer Protection. Toxins 2018, 10, 324. [CrossRef] [PubMed]

2. Otero, P.; Rodríguez, P. Marker Compounds, Relative Response Factors, and Toxic Equivalent Factors. In Seafood and Freshwater Toxins, 3rd ed.; Botana, L.M., Ed.; CRC Press: Boca Raton, FL, USA, 2014; pp. 57-77.

3. Otero, P.; Alfonso, C. Analysis of Marine Toxins: Gaps on food safety control of marine toxins. In Phycotoxins: Chemistry and Biochemistry; Botana, L.M., Alfonso, A., Eds.; John Wiley \& Sons, Ltd.: Hoboken, NJ, USA, 2015; pp. 1-21.

4. European Commission. Regulation (EU) No 853/2004 of the European Parliament and of the Council of 29 April 2004 laying down specific hygiene rules for food of animal origin. Off. J. Eur. Union L 2004, 139, 55-205.

5. European Commission. Regulation (EU) No 786/2013 of 16 August 2013 amending Annex III to Regulation (EC) No 853/2004 of the European Parliament and of the Council as regards the permitted limits of yessotoxins in live bivalve molluscs. Off. J. Eur. Union L 2013, 220, 14.

6. European Commission. Regulation (EU) No 15/2011 of 10 January of 2011 amending Regulation (EC) No 2074/2005 as regards recognised testing methods for detecting marine biotoxins in live bivalve molluscs. Off. J. Eur. Union L 2011, 6, 3-6. 
7. Rundberget, T.; Aasen, J.A.; Selwood, A.I.; Miles, C.O. Pinnatoxins and spirolides in Norwegian blue mussels and seawater. Toxicon 2011, 58, 700-711. [CrossRef]

8. García-Altares, M.; Casanova, A.; Bane, V.; Diogène, J.; Furey, A.; de la Iglesia, P. Confirmation of pinnatoxins and spirolides in shellfish and passive samplers from Catalonia (Spain) by liquid chromatography coupled with triple quadrupole and high-resolution hybrid tandem mass spectrometry. Mar. Drugs 2014, 12, 3706-3732. [CrossRef]

9. Molgó, J.; Marchot, P.; Aráoz, R.; Benoit, E.; Iorga, B.I.; Zakarian, A.; Taylor, P.; Bourne, Y.; Servent, D. Cyclic imine toxins from dinoflagellates: A growing family of potent antagonists of the nicotinic acetylcholine receptors. J. Neurochem. 2017, 142 (Suppl. 2), 41-51. [CrossRef]

10. Rambla-Alegre, M.; Miles, C.O.; de la Iglesia, P.; Fernandez-Tejedor, M.; Jacobs, S.; Sioen, I.; Verbeke, W.; Samdal, I.A.; Sandvik, M.; Barbosa, V.; et al. Occurrence of cyclic imines in European commercial seafood and consumers risk assessment. Environ. Res. 2018, 161, 392-398. [CrossRef]

11. Lamas, J.P.; Arévalo, F.; Moroño, Á.; Correa, J.; Muñíz, S.; Blanco, J. Detection and Spatio-Temporal Distribution of Pinnatoxins in Shellfish from the Atlantic and Cantabrian Coasts of Spain. Toxins 2019, 11, 340. [CrossRef]

12. Otero, P.; Miguéns, N.; Rodríguez, I.; Botana, L.M. LC-MS/MS analysis of the emerging toxin pinnatoxin-G and high levels of esterified OA group toxins in Galician commercial mussels. Toxins 2019, 11, 394. [CrossRef]

13. Moreiras, G.; Leao, J.; Gago-Martínez, A. Analysis of Cyclic Imines in Mussels (Mytilus galloprovincialis) from Galicia (NW Spain) by LC-MS/MS. Int. J. Environ. Res. Public Health 2020, 17, 281. [CrossRef] [PubMed]

14. Arnich, N.; Abadie, E.; Delcourt, N.; Fessard, V.; Fremy, J.M.; Hort, V.; Lagrange, E.; Maignien, T.; Molgó, J.; Peyrat, M.-B.; et al. Health Risk Assessment Related to Pinnatoxins in French Shellfish. Toxicon 2020, 180, 1-10. [CrossRef] [PubMed]

15. Otero, P.; Alfonso, A.; Alfonso, C.; Aráoz, R.; Molgó, J.; Vieytes, M.R.; Botana, L.M. First direct fluorescence polarization assay for the detection and quantification of spirolides in mussel samples. Anal. Chim. Acta 2011, 701, 200-208. [CrossRef]

16. Munday, R. Imines: Gymnodimine, Spirolides, Pinnatoxins, Pteriatoxins, Prorocentrolide, Spiro-Prorocentrimine, and Symbioimines. In Seafood and Freshwater Toxins: Pharmacology, Physiology and Detection, 2nd ed.; Botana, L.M., Ed.; CRC Press Taylor and Francis Group: New York, NY, USA, 2008; pp. 581-594.

17. EFSA Panel on Contaminants in the Food Chain (CONTAM). Scientific Opinion on marine biotoxins in shellfish-Cyclic imines (spirolides, gymnodimines, pinnatoxins and pteriatoxins). EFSA J. 2010, 8, 1628. [CrossRef]

18. Otero, P.; López-Martínez, M.; García-Risco, M. Application of pressurized liquid extraction (PLE) to obtain bioactive fatty acids and phenols from Laminaria ochroleuca collected in Galicia (NW Spain). J. Pharm Biomed. Anal. 2019, 164, 86-92. [CrossRef] [PubMed]

19. Camacho, F.; Macedo, A.; Malcata, F. Potential Industrial Applications and Commercialization of Microalgae in the Functional Food and Feed Industries: A Short Review. Mar. Drugs 2019, 17, 312. [CrossRef]

20. Otero, P.; Quintana, S.E.; Reglero, G.; Fornari, T.; García-Risco, M.R. Pressurized Liquid Extraction (PLE) as an Innovative Green Technology for the Effective Enrichment of Galician Algae Extracts with High Quality Fatty Acids and Antimicrobial and Antioxidant Properties. Mar. Drugs 2018, 16, 156. [CrossRef]

21. Brien, S.; Prescott, P.; Coghlan, B.; Bashir, N.; Lewith, G. Systematic review of the nutritional supplement Perna Canaliculus (green-lipped mussel) in the treatment of osteoarthritis. QJM Int. J. Med. 2008, 101, 167-179. [CrossRef]

22. European Parliament. Regulation (EC) No 178/2002 of the European Parliament and of the Council of 28 January 2002 laying down the general principles and requirements of food law, establishing the European Food Safety Authority and laying down procedures in matters of food safety. Off. J. Eur. Union L 2002, 031, 1-24.

23. Biesterbos, J.W.H.; Sijm, D.T.H.M.; van Dam, R.; Mol, H.G.J. A Health Risk for Consumers: The Presence of Adulterated Food Supplements in the Netherlands. Food Addit. Contam. Part A 2019, 36, 1273-1288. [CrossRef]

24. Hess, P.; Abadie, E.; Hervé,, F.; Berteaux, T.; Séchet, V.; Aráoz, R.; Molgó, J.; Zakarian, A.; Sibat, M.; Rundberget, T.; et al. Pinnatoxin G is responsible for atypical toxicity in mussels (Mytilus galloprovincialis) and clams (Venerupis decussata) from Ingril, a French Mediterranean lagoon. Toxicon 2013, 75, 16-26. [PubMed] 
25. European Union Reference Laboratory for Marine Biotoxins. EU-Harmonised Standard Operating Procedure for Determination of Lipophilic Marine Biotoxins in Molluscs by LC-MS/MS; Version 5; Campus Universitario de Vigo: Vigo, Spain, 2015; Available online: http://www.aecosan.msssi.gob.es/AECOSAN/docs/documentos/ laboratorios/LNRBM/ARCHIVO2EU-Harmonised-SOP-LIPO-LCMSMS_Version5.pdf (accessed on 27 July 2020).

26. Ovissipour, M.; Rasco, B.; Tang, J.; Sablani, S.S. Kinetics of quality changes in whole blue mussel (Mytilus edulis) during pasteurization. Food Res. Int. 2013, 53, 141-148. [CrossRef]

27. Otero, P.; Alfonso, A.; Vieytes, M.R.; Cabado, A.G.; Vieites, J.M.; Botana, L.M. Effects of environmental regimens on the toxin profile of Alexandrium ostenfeldii. Environ. Toxicol. Chem. 2010, 29, 301-310. [CrossRef] [PubMed]

28. Salgado, P.; Riobó, P.; Rodríguez, F.; Franco, J.M.; Bravo, I. Differences in the toxin profiles of Alexandrium ostenfeldii (Dinophyceae) strains isolated from different geographic origins: Evidence of paralytic toxin, spirolide, and gymnodimine. Toxicon 2015, 103, 85-98. [CrossRef] [PubMed]

29. Davidson, K.; Baker, C.; Higgins, C.; Higman, W.; Swan, S.; Veszelovszki, A.; Turner, A.D. Potential Threats Posed by New or Emerging Marine Biotoxins in UK Waters and Examination of Detection Methodologies Used for Their Control: Cyclic Imines. Mar. Drugs 2015, 13, 7087-7112. [CrossRef]

30. Uemura, D.; Chou, T.; Haino, T.; Nagatsu, A.; Fukuzawa, S.; Zheng, S.; Chen, H. Pinnatoxin A: A toxicamphoteric macrocycle from the Okinawan bivalve Pinna muricata. J. Am. Chem. Soc. 1995, 117, 1155-1156. [CrossRef]

31. Selwood, A.I.; Miles, C.O.; Wilkins, A.L.; van Ginkel, R.; Munday, R.; Rise, F.; McNabb, P. Isolation andstructural determination, and acute toxicity of novel pinnatoxins E, F and G. J. Agric. Food Chem. 2010, $58,6532-6542$.

32. McNabb, P.S.; McCoubrey, D.J.; Rhodes, L.; Smith, K.; Selwood, A.I.; van Ginkel, R.; MacKenzie, A.L.; Munday, R.; Holland, P.T. New perspectives on biotoxin detection in Rangaunu Harbour, New Zealand arising from the discovery of pinnatoxins. Harmful Algae 2012, 13, 34-39. [CrossRef]

33. McCarron, P.; Rourke, W.A.; Hardstaff, W.; Pooley, B.; Quilliam, M.A. Identification of Pinnatoxins and Discovery of Their Fatty Acid Ester Metabolites in Mussels (Mytilus Edulis) From Eastern Canada. J. Agric. Food Chem. 2012, 60, 1437-1446. [CrossRef]

34. Aráoz, R.; Barnes, P.; Séchet, V.; Delepierre, M.; Zinn-Justin, S.; Molgó, J.; Zakarian, A.; Hess, P.; Servent, D. Cyclic imine toxins survey in coastal european shellfish samples: Bioaccumulation and mode of action of 28-O-palmitoyl ester of pinnatoxin-G. First report of portimine-A bioaccumulation. Harmful Algae 2020, 98, 101887.

35. Sosa, S.; Pelin, M.; Cavion, F.; Hervé, F.; Hess, P.; Tubaro, A. Acute Oral Toxicity of Pinnatoxin G in Mice. Toxins 2020, 28, 87. [CrossRef] [PubMed]

36. Blanco, J.; Arévalo, F.; Moroño, A.; Correo, J.; Muñíz, S.; Mariño, C.; Martín, H. Presence of azaspiracids in bivalve molluscs from Northern Spain. Toxicon 2017, 137, 135-143. [CrossRef] [PubMed]

37. López-Rivera, A.; O'Callaghan, K.; Moriarty, M.; O’Driscoll, D.; Hamilton, B.; Lehane, M.; James, K.J.; Furey, A. First evidence of azaspiracids (AZAs): A family of lipophilic polyether marine toxins in scallops (Argopecten purpuratus) and mussels (Mytilus chilensis) collected in two regions of Chile. Toxicon 2010, 55, 692-701. [CrossRef] [PubMed]

38. EFSA. Scientific Opinion of the Panel on Contaminants in the Food Chain on a Request from the European Commission on Marine Biotoxins in Shellfish—Summary on regulated marine biotoxins. EFSA J. 2008, 1306, $1-23$.

39. EFSA. Scientific Opinion of the Panel on Contaminants in the Food Chain on a Request from the European Commission on Marine Biotoxins in Shellfish-Azaspiracids. EFSA J. 2008, 723, 1-52.

40. Pelin, M.; Kilcoyne, J.; Nulty, C.; Crainc, S.; Hess, P.; Tubaro, A.; Sosa, S. Toxic equivalency factors (TEFs) after acute oral exposure of azaspiracid 1,-2 and -3 in mice. Toxicol. Lett. 2018, 282, 136-146. [CrossRef]

41. Garcia, C.; Rodriguez-Unda, N.; Contreras, C.; Barriga, A.; Lagos, N. Lipophilic toxin profiles detected in farmed and benthic mussels populations from the most relevant production zones in Southern Chile. Food Addit. Contam. Part A Chem Anal. Control. Expo. Risk Assess. 2012, 29, 1011-1020. [CrossRef] 
42. Miles, C.O.; Wilkins, A.L.; Munday, R.; Dines, M.H.; Hawkes, A.D.; Briggs, L.R.; Sandvik, M.; Jensen, D.J.; Cooney, J.M.; Holland, P.T.; et al. Isolation of pectenotoxin-2 from Dinophysis acuta and its conversion to pectenotoxin-2 seco acid, and preliminary assessment of their acute toxicities. Toxicon 2004, 43, 1-9. [CrossRef]

43. EFSA. Scientific Opinion of the Panel on Contaminants in the Food chain on a Request from the European Commission Marine Biotoxins in Shellfish-Pectenotoxin Group. EFSA J. 2009, 1109, 1-47.

44. Alarcan, J.; Biré, R.; Le Hégarat, L.; Fessard, V. Mixtures of Lipophilic Phycotoxins: Exposure Data and Toxicological Assessment. Mar. Drugs 2018, 16, 46. [CrossRef]

45. Wu, H.; Guo, M.; Tan, Z.; Cheng, H.; Li, Z.; Zhai, Y. Liquid chromatography quadrupole linear ion trap mass spectrometry for multiclass screening and identification of lipophilic marine biotoxins in bivalve mollusks. J. Chromatogr. A 2014, 1358, 172-180. [CrossRef] [PubMed]

46. Hu, T.; Curtis, J.M.; Oshima, Y.; Quilliam, M.A.; Walter, J.A.; Wright, W.M.; Wright, J.L.C. Spirolides B and D, two novel macrocycles isolated from the disgestive glands of shellfish. J. Chem. Soc. Chem. Commun. 1995, 20, 2159-2161. [CrossRef]

47. Silva, M.; Barreiro, A.; Rodriguez, P.; Otero, P.; Azevedo, J.; Alfonso, A.; Botana, L.M.; Vasconcelos, V. New Invertebrate Vectors for PST, Spirolides and Okadaic Acid in the North Atlantic. Mar. Drugs 2013, 11, 1936-1960. [CrossRef] [PubMed]

48. Suleria, H.A.R.; Osborne, S.; Masci, P.; Gobe, G. Marine-Based Nutreceuticals: As Innovative Trend in the Food and Supplement Industries. Mar. Drugs 2015, 13, 6336-6351. [CrossRef]

49. Cobb, C.; Ernst, E. Systematic review of a marine nutriceutical supplement in clinical trials for arthritis: The effectiveness of the New Zealand green-lipped mussel Perna canaliculus. Clin. Rheumatol. 2006, 25, 275-284. [CrossRef]

50. Treschow, A.; Hodges, L.D.; Wright, P.F.A.; Wynne, P.M.; Kalafatis, N.; Macrides, T.A. Novel Anti-Inflammatory Omega-3 PUFAs from the New Zealand Green-Lipped Mussel, Perna Canaliculus. Comp. Biochem. Physiol. B Biochem. Mol. Biol. 2007, 147, 645-656. [CrossRef]

51. Costa, J.; Vidovic, B.; Saraiva, N.; do Céu Costa, M.; Del Favero, G.; Marko, D.; Oliveira, N.G.; Fernandes, A.S. Contaminants: A dark side of food supplements? Free Radic. Res. 2019, 53, 1113-1135. [CrossRef]

52. MacKenzie, L.; Holland, P.; McNabb, P.; Beuzenberg, V.; Selwood, A.; Suzuki, T. Complex Toxin Profiles in Phytoplankton and Greenshell Mussels (Perna Canaliculus), Revealed by LC-MS/MS Analysis. Toxicon 2002, 40, 1321-1330. [CrossRef]

53. Dom, I.; Biré, R.; Hort, V.; Lavison-Bompard, G.; Nicolas, M.; Guérin, T. Extended Targeted and Non-Targeted Strategies for the Analysis of Marine Toxins in Mussels and Oysters by (LC-HRMS). Toxins 2018, 10, 375. [CrossRef]

54. European Commission. Commission decision 2002/657/EC implementing Council directive 96/23/EC concerning the performance of analytical methods and the interpretation of results. Off. J. Eur. Communities 2002, 221, 8-36.

(C) 2020 by the authors. Licensee MDPI, Basel, Switzerland. This article is an open access article distributed under the terms and conditions of the Creative Commons Attribution (CC BY) license (http://creativecommons.org/licenses/by/4.0/). 